\title{
ARTIGO
}

\section{Exclusão digital e exclusão social: elementos para uma discussão}

\section{Digital exclusion and social exclusion: subject for discussion}

Fernando Augusto Mansor MATTOS ${ }^{1}$

\begin{abstract}
"A exclusão digital não é ficar sem computador ou telefone celular. É continuarmos incapazes de pensar, de criar e de organizar novas formas, mais justas e dinâmicas, de produção e distribuição da riqueza simbólica e material".
\end{abstract}

(Schwartz, 2000)

\section{R E S U M O}

O presente artigo tem por objetivo descrever e interpretar de forma crítica o papel que as novas Tecnologias da Informação e da Comunicação têm desempenhado no recente processo de "globalização". Essa avaliação será feita para o conjunto da economia mundial e para o Brasil, em particular. A hipótese que deve nortear este trabalho é a de que as novas tecnologias da Informação e da Comunicação tendem a ampliar o padrão de exclusão social vigente no atual momento histórico do Capitalismo. E também reproduzem, de forma ampliada, as assimetrias existentes entre os países, promovidas pelo processo de globalização econômica. Este estudo chama a atenção para o papel estratégico que adquire o acesso às informações promovido pelas novas

1 Professor e Pesquisador do Programa de Pós-Graduação em Ciência da Informação, Professor de Economia do Centro de Economia e Administração (CEA), Pontifícia Universidade Católica de Campinas. Praça da I maculada, 105, Vila Santa Odila, 13045-901, Campinas, SP, Brasil. E-mail: fermatt@uol.com.br 
Tecnologias da Informação e da Comunicação e destaca como a exclusão digital determina novas formas de exclusão social.

Palavras-chave: exclusão digital, exclusão social, tecnologias da informação, comunicação.

\section{A B S T R A C T}

This paper analytically describes and interprets the role performed by the new Information and Communication Technologies in the recent "globalization" process. This evaluation encompasses the complex of world's economy and, in particular, that of Brazil. The project's guiding hypothesis presumes that the new Information and Communication Technologies tend to amplify the social exclusion pattern already existing at the current historical period of the Capitalism. Besides, it assumes that those technologies reproduce, in amplified forms, the asymmetries existing among the countries, which are promoted by the economic globalization process. This study also alerts to the strategic role invested in the access to information, as promoted by the new Information and Communication Technologies, and emphasizes how the digital exclusion develops new forms of social exclusion.

Key words: digital exclusion, social exclusion, Information and communication technologies.

\section{N T R O D U Ç Ã O}

As transformações pelas quais passou 0 capitalismo, nas últimas décadas do século XX, foram, caracterizadas de variadas formas por autores vinculados ao pensamento hegemônico², mas, em todas essas conceitualizações, estão presentes as idéias de que estaríamos vivendo (notadamente na segunda metade da década de 1990) uma era de prosperidade baseada em notáveis ganhos de produtividade, em expansão das novas tecnologias para todos os países do mundo e, de uma globalização que estaria fazendo confluírem todas as economias nacionais a padrões semelhantes de política econômica - notadamente, políticas de privatização e de abertura comercial e financeira, que seriam, então, a chave para o progresso material e social. As interpretações mais apologéticas sobre as recentes transformações promovidas pelas novas Tecnologias da Informação e da Comunicação (TIC), base da expansão recente da economia americana, destacam que as mesmas seriam responsáveis por uma contínua aproximação entre os povos e entre as Nações, constituindo elemento integrador, tanto em termos sociais, quanto em termos econômicos e culturais.

Entre 1994 e 2000, a economia americana teve seu mais longo período de prosperidade

\footnotetext{
2 Bell (1973) caracteriza a era recente como uma sociedade pós-industrial; Castells (1999) postula o conceito de sociedade informacional; O hmae (1996) fala de uma era marcada pelo fim do Estado-N ação; Fukuyama (1992) trata o momento atual como o "fim da História", o que representaria o triunfo definitivo do pensamento econômico liberal.
} 
desde o pós-guerra ${ }^{3}$. A expansão da Internet (e dos negócios por ela proporcionados) representa não só o maior símbolo das novas tecnologias em que se baseou essa prosperidade, como também a suposta comprovação de que estaríamos adentrando, finalmente, em um mundo sem fronteiras e de decadência dos Estados Nacionais (OHMAE, 1996).

Em 1994, o governo dos EUA anunciou o seu projeto de constituição de uma Global Information Infrastructure ${ }^{4}$. A partir desse momento, a imprensa de todo o mundo e mesmo alguns segmentos da academia passaram a tratar da existência de uma "nova economia", representada, basicamente, pelas atividades ligadas direta ou indiretamente à Internet e ao complexo produtivo das telecomunicações e da informática (as TIC). O fascínio exercido pelas novas tecnologias da informação gerou, em alguns autores, não só a expectativa de que a expansão econômica da segunda metade da década de 1990 seria perene, como também criou em alguns a impressão de que a Internet poderia representar uma forma de romper todas as barreiras de comunicações entre os países e as pessoas. Mais do que isso, a expansão das redes de comunicação pela Internet, segundo o pensamento dominante, seria responsável pela inclusão de toda a população mundial no universo das informações e, enfim, por uma suposta "Democracia Global"5. Passados os momentos de euforia gerados pela expansão da economia americana (e, depois, da economia européia), que, como se sabe, entrou em trajetória descendente no início do ano de 2001, começam a ser questionados alguns dos pressupostos otimistas que haviam sido externados nos anos da bonança. Nesse contexto, inicia-se, nos meios acadêmicos, um debate a respeito da "infoexclusão/infoinclusão", normalmente avaliada segundo as estatísticas de acesso da população de cada país ou de cada região a um terminal de computador que possa se conectar à Internet.

O presente artigo tem por objetivo descrever e interpretar de forma crítica o papel que as novas Tecnologias da Informação e da Comunicação (TIC) têm desempenhado no recente processo de "globalização"6. Essa avaliação será feita para o conjunto da economia mundial e para o Brasil, em particular. A hipótese que deve nortear este trabalho é a de que as novas tecnologias da Informação e da Comunicação tendem a ampliar o padrão de exclusão social vigente no atual momento histórico do

\footnotetext{
${ }^{3} \mathrm{Não}$ cabe aqui uma longa explanação das razões da prosperidade da economia americana. Alguns estudos podem ser indicados para esta discussão: Mattos (2001), Brenner (2003), Coutinho \& Belluzzo (1998). Basicamente, a prosperidade americana no período fundou-se num processo de valorização especulativa de ações em Bolsa das empresas da chamada "nova economia" (empresas de telecomunicações, de biotecnologia, de negócios pela Internet etc.), fomentado pela atração de recursos externos pela economia americana, quese beneficiou dos momentos de instabilidade da ordem financeira internacional (TAVARES, 1997), quando os especuladores financeiros de todo o mundo aplicavam partes crescentes de sua riqueza em ações em Bolsa de Valores ou em títulos do Tesouro americano para se protegerem de perdas patrimoniais em contexto de elevada instabilidade do capitalismo globalizado. Esse processo de endividamento externo da economia americana acabou impulsionando o valor das ações de grandes empresas americanas, as quais, por sua vez, "alavancavam" créditos junto ao mercado financeiro para realizarem novos aportes de investimentos na expansão de suas respectivas capacidades produtivas, oferecendo as próprias ações val orizadas como garantia para os créditos tomados. Da mesma maneira, as famílias americanas ampliavam, no mercado financeiro doméstico, seu endividamento, lastreado pelas próprias ações (em contínua valorização) que mantinham em carteira. Dessa forma, a demanda agregada expandiu-se como nunca antes desde o pós-guerra, por causa dos investimentos produtivos das empresas e devido ao consumo das famílias. A partir de 2001, porém, surgem os primeiros sinais da desacel eração, quando se consolida a percepção, segundo a qual, a relação entre os preços das ações e a lucratividade das empresas (especialmente as "ponto com") se distanciavam cada vez mais e, também, a partir da constatação, por parte dos agentes econômicos, de que estava formando-se uma crescente capacidade ociosa nas empresas da chamada "nova economia", o que gerou nas mesmas uma atitude de retração de novos investimentos que, enfim, acabou arrastando toda a economia americana para a recessão. Os acontecimentos de 11 de setembro de 2001 acabaram por acelerar esse processo de retração da economia americana.

${ }^{4} \mathrm{Na}$ ocasião, segundo Lozada (2003), o vice-presidente americano Al Gore anunciava "a nova era ateniense da democracia".

5 Bolaño (2003a) se alinha entre os críticos dessa proposição apologética.

6 "Globalização" entendida como as recentes transformações sofridas pela ordem internacional segundo seus aspectos econômicos, políticos e histórico-sociais.
} 
Capitalismo. E também reproduzem, de forma ampliada, as assimetrias existentes entre os países, promovidas pelo processo de globalização econômica. A importância de tal estudo se justifica pelo fato de que a informação assume, nas sociedades atuais, papel cada vez mais estratégico. $\mathrm{O}$ acesso às informações e, notadamente, a capacidade de transformar informações em conhecimento, são fatores decisivos de inclusão social ${ }^{7}$.

Trata-se, portanto, não somente de discutir a ampliação do acesso às tecnologias da informação, mas também - o que é muito importante - de dotar todos os estratos sociais ${ }^{8}$ de condições cognitivas adequadas para também poderem processar as informações, transformando-as em conhecimento, o que amplia as possibilidades de inserção nos mercados de trabalho ${ }^{9}$ e, também, permite o acesso a atributos fundamentais da construção da cidadania nos tempos atuais.

Este artigo está dividido em 3 partes, além desta breve introdução. Na primeira parte, são apresentadas duas visões antagônicas (uma que chamaremos de visão hegemônica e outra, de visão crítica) a respeito das características do atual processo de globalização e da expansão das Tecnologias da Informação e da Comunicação, nesse contexto de transformações geradas pela globalização econômica e cultural. Na segunda parte, apresentamos um breve painel ilustrativo da concentração de renda e da exclusão digital no Brasil. Na terceira parte, problematizamos a questão da exclusão digital no atual contexto capitalista, destacando o caráter assimétrico e o potencial excludente da difusão das TIC, principalmente em um país como o Brasil, estruturalmente marcado por elevados graus de concentração de renda, de riqueza e do saber. Por fim, fazemos alguns comentários a título de conclusões.

A interpretação "otimista" a respeito das possibilidades de inclusão digital propalada por certos autores ${ }^{10}$ é resultante, segundo pretendemos mostrar, de uma certa visão, também glorificadora e ufanista, a respeito da natureza do chamado processo de globalização econômica atualmente em curso no Capitalismo. De nossa parte, pretendemos, além de interpretar criticamente a globalização econômica e as possibilidades que as chamadas novas tecnologias colocam para a ampliação da inclusão digital (e também da inclusão social supostamente a ela associada), também avaliar de maneira mais rigorosa os indicadores de inclusão/exclusão digital normalmente apresentados.

7 Nesse sentido, as palavras de Silveira (2001, p.15) são esclarecedoras: "enquanto a primeira e a segunda revoluções tecnológicas ampliaram a capacidade física e a precisão das atividades humanas, esta revolução (informacional) amplifica a mente. Eis o maior perigo de se chegar atrasado a ela. Essa revolução, exatamente por fundar-se nas tecnologias da inteligência, amplia exponencial mente as diferenças na capacidade de tratar informações e transformá-las em conhecimento. Por isso, essa revolução não apenas pode consolidar desigualdades sociais como também elevá-las, pois aprofunda o distanciamento cognitivo entre aqueles que já convivem com ela e os que dela estão apartados".

8 Conforme ressalta Silveira (2001, p.21), “(...) os agrupamentos sociais que não souberem manipular, reunir, desagregar, processar e analisar informações ficarão distantes da produção do conhecimento, estagnados ou vendo se agravar sua condição de miséria".

9 Silveira (2001, p.18) também nos ajuda a compreender porque a exclusão digital pode aprofundar a exclusão social: "além de ser um veto cognitivo e um rompimento com a mais liberal das idéias de igualdade formal e de direito de oportunidade, a exclusão digital impede que se reduza a exclusão social, uma vez que as principais atividades econômicas, governamentais e boa parte da produção cultural vão migrando para a rede, sendo praticadas e divulgadas por meio da comunicação informacional. Estar fora da rede é ficar fora dos principais fluxos de informação. Desconhecer seus procedimentos básicos é amargar a nova ignorância".

${ }^{10}$ N otadamente, os autores não vinculados à Economia Política da Informação e do Conhecimento, como os citados na nota de rodapé número 2 . 
CARACTERÍSTICAS DO ATUAL

PROCESSO DE GLOBALIZAÇÃ O E DE EXPANSÃO DAS TECNOLOGIAS

DA IN FORM A ÇÃ O E D C O M U NICA ÇÃ O: A INTERPRETAÇÃ O DO PENSAMENTO HEGEM Ô NICO E A VISÃO CRÍTICA

Existe consenso de que, desde o pós-guerra, foram muito significativas as mudanças promovidas pela globalização econômica e pelas novas tecnologias. Há controvérsia, porém, sobre as causas e a natureza dessas transformações.

Nesse contexto, a expansão das empresas de tecnologias da informação foi bastante expressiva, notadamente na última década do século ${ }^{11}$. O desempenho econômico excepcional das empresas produtoras de tecnologias da informação e da Comunicação deu margem a que certos autores alcunhassem o Capitalismo do final do século de Era da Informação (CASTELLS, 1999). A literatura econômica hegemônica, exalta a expansão econômica dos EUA na década de 1990 como uma era de prosperidade baseada na chamada Nova Economia, a partir da qual a expansão da produção nos setores econômicos de ponta seria contínua (e, segundo alguns, perene), baseada nos ganhos de produtividade produzidos pelos setores que representados pelas novas TIC's.

A abertura de mercados e a liberalização dos fluxos de investimentos financeiros, que se acentuaram a partir de meados dos anos 1980, representariam um impulso decisivo no processo de globalização, tido como homogeneizador e promotor do bem-estar dos povos e da paz mundial. O "fim das ideologias", dada a propalada "vitória definitiva" do Capitalismo, consagrava o Liberalismo como a ideologia à qual todos deveriam convergir, caso almejassem obter prosperidade social e econômica. No âmbito da desregulamentação dos fluxos de capital financeiro, o livre movimento desses capitais aumentaria a eficiência do sistema econômico mundial e promoveria uma eqüalização entre as taxas de juros dos diversos países, propiciando uma alocação ótima de recursos. A abertura da fronteiras econômicas e a ampliação do comércio e dos investimentos favoreceria, especialmente, os países mais pobres (sempre segundo o pensamento econômico liberal, que se torna hegemônico a partir dos anos 1980 do século $X X)$.

Para esses autores ${ }^{12}$, na maior parte das vezes formados no pensamento econômico de extração neoclássica, a globalização seria resultante de um processo meramente econômico produzido pelas forças de mercado e impulsionada pela revolução informacional que se generaliza na década de 1990. O sociólogo Manuel Castells, embora não vinculado, originalmente, em sua trajetória acadêmica, ao pensamento liberal-neoclássico, compartilha com autores dessa origem de pensamento da mesma retórica ufanista e otimista a respeito do papel das tecnologias no mundo globalizado, notadamente da Internet, seu maior símbolo. Segundo Castells (1999), a ampliação da Internet seria capaz de produzir uma transformação mundial que levaria à convergência de renda, riqueza, oportunidades e informações. O autor afirma que a expansão da Internet poderia funcionar como um verdadeiro "Plano Marshall tecnológico Norte-Sul (...), incluindo a maioria

\footnotetext{
${ }^{11}$ Artigo recente de Brenner (2003) destaca que apesar do setor das novas tecnologias da informação representar apenas cerca de $8 \%$ do PIB americano, ele foi responsável por quase um terço do crescimento total do PIB americano entre 1995 e 1999.

12 Ohmae (1996) e Fukuyama (1992) são apenas dois dos mais famosos representantes dessa linha de pensamento.
} 
da humanidade nas redes de informação e riqueza"13.

Do lado oposto do debate, encontram-se pensadores sociais que destacam que as transformações promovidas no pós-guerra são fruto da atuação política dos Estados Nacionais mais fortes (especialmente o americano) e que, nesse contexto, as novas tecnologias tiveram papel importante, mas que não se sobrepõem às medidas estratégicas tomadas pelos Estados Nacionais dos países capitalistas mais ricos, com o intuito de reforçar sua hegemonia no mundo. Nesse sentido, as políticas desregulacionistas ${ }^{14}$ do mercado financeiro tomadas pelos governos liberais de Reagan e Thatcher, nos anos 1980, obrigaram os demais países do mundo a também adota-lás, sob pena de sofrerem pesadas perdas de capitais. Essas medidas acabaram por reforçar o peso financeiro das praças já hegemônicas de Nova York e Londres, aumentando a assimetria financeira internacional.

Ainda antes de deslancharem essa ofensiva pela "desregulamentação competitiva", o governo dos EUA já havia rompido, em 1971, com o sistema de Bretton Woods, que atrelava o dólar a uma porção fixa em ouro ${ }^{15}$, e já haviam

13 Esse "tecno-otimismo" de Castells não é surpresa para os que examinaram com o cuidado merecido sua mais conhecida obra (CASTELLS, 1999). Nesse livro, Castells defende, fundamentalmente, a idéia de que estaríamos entrando em uma nova Era do Informacionalismo, caracterizada por uma nova estrutura social "global", a Sociedade em Rede. A mudança fundamental estaria sendo operada pela substituição de um modo de produção industrial por um modo de produção informacional. Esta mudança fundamental estaria sendo conduzida aceleradamente por mudanças tecnológicas promovidas pelas Tecnologias da Informaçãa e da Comunicação, as quais, por sua vez, estariam promovendo significativos ganhos de produtividade na atividade produtiva. 0 autor destaca como setores líderes desse novo paradigma tecnológico as inovações ocorridas especial mente no Vale do Silício a partir dos anos 70. Baseado na descrição dessas mudanças tecnológicas, Castells analisa as mudanças ocorridas nas estruturas produtivas, sociais e dos mercados de trabal ho dos principais países capitalistas. No âmbito empresarial, segundo o autor, as organizações passariam a operar em rede, interconectadas em um mercado global. N esse contexto de integração mundial em redes, as dimensões do tempo e do espaço tornam-se cada vez menos relevantes. A operação das organizações em rede permitiria às mesmas usufruir das inovações de forma mais acelerada e também coordenar a cadeia produtiva de forma mais integrada dentro do espaço global. A ênfase de Castells no determinismo tecnológico das transformações enumeradas encerra diversos problemas, segundo a crítica rigorosa que N icholas Garnham (2000), representante emérito da escola inglesa da Economia Política da Comunicação. Para Garnham (2000), Castells (1999) não consegue sustentar seu argumento central, segundo o qual a atual Era da Informação estaria sendo caraterizada por expressivos ganhos de produtividade decorrentes do uso das TIC. De fato, Mattos (2001) (embora sem o intuito específico de criticar a obra de Castells) mostra que os ganhos de produtividade média horária do trabalho dos anos $50 \mathrm{~s} / 60 \mathrm{~s}$ são bastante mais expressivos do que os ganhos de produtividade média horária do trabalho nas duas últimas décadas do século XX. Garnham (2000) critica o caráter alienante das formulações da obra de Castells (2000), lembrando que a ênfase no determinismo tecnológico do autor o impede de avaliar os importantes aspectos sócio/políticos e mesmo os econômicos envolvidos na produção, disseminação e acesso às tecnologias da informação. Para uma leitura mais acurada dessas críticas, cf. Garnham (2000); para uma revisão bibliográfica desse trabalho de Garnham (2000), cf. Bolaño e Mattos (2003), mimeo.

14 Medidas legais e institucionais voltadas a facilitar os fluxos de capitais financeiros entre países e entre diferentes segmentos do sistema bancário, tornando-os mais "livres" e menos custosos, ao mesmo tempo em que aumentavam as taxas de juros e reduziam as taxações das aplicações financeiras, para atrair capitais financeiros de todos os cantos do mundo.

$15 \mathrm{~N}$ ão cabe aqui fazer uma recuperação exaustiva da literatura que trata das transformações ocorridas na ordem financeira internacional durante o pós-guerra. Vale apenas mencionar que, na Conferência de Bretton Woods, ocorrida em julho de 1994, em uma pequena cidade do estado americano de $\mathrm{N}$ ew Hampshire, foram tomadas medidas que objetivavam estabilizar as taxas de câmbio entre as principais moedas (coibindo as especulações cambiais) e criar um ambiente para a retomada do comércio internacional e para a reconstrução européia. Dessa maneira, foi estabelecido o padrão dólar-ouro, a partir da fixação de uma relação de US\$ 35 por onça de ouro, relação que o Tesouro americano se comprometia a honrar aos países que desejassem converter suas reservas de dólares em ouro. Ao mesmo tempo, as demais moedas teriam taxas praticamente estáveis em relação ao dólar e, por conseguinte, também em relação ao ouro. Isso promoveu, durante certo tempo, uma importante estabilidade entre as taxas cambiais, facilitando o comércio internacional entre os países. Os horrores da segunda guerra mundial haviam deixado como legado um consenso segundo o qual os Estados Nacionais deveriam concentrar esforços para que as políticas econômicas dos países capitalistas pudessem promover políticas voltadas ao pleno emprego. Para cumprir esse objetivo principal, foram adotadas medidas de controle dos fluxos de capitais financeiros entre os países, isolando-os dos efeitos perversos que uma livre movimentação de capitais financeiros pudesse ter sobre os Bancos Centrais de cada Nação, impedindo-os de colocar a política monetária em função dos objetivos de pleno emprego. Toda essa construção, porém, foi demonstrando seu esgotamento, quando as oportunidades abertas pela reconstrução aos novos investimentos produtivos começavam a se esgotar à medida que a mesma ia sendo concluída. 0 fato que mais pesou para a derrocada do Sistema de Bretton Woods foi a crescente falta de compromisso dos americanos com o sistema financeiro internacional organizado no imediato pós-guerra, que Ihes legava uma certa limitação para fazer sua política econômica doméstica e para aumentar a emissão de dólar, por causa do compromisso com a paridade com o ouro, cuja produção era menos elástica do que as necessidades de emissão de moeda por parte dos americanos, especialmente quando os mesmos precisavam fazer frente aos crescentes gastos externos com a Guerra do Vietnã e com sua balança comercial cada vez mais deficitária. Para não sacrificar seus interesses estratégicos e bélicos, e para não comprometer a prosperidade consumista do povo americano, os EUA anunciam, em 1971, que não mais honrariam a paridade dólar-ouro - o que jogou o mundo em uma evolução de instabilidade sem que a moeda americana perdesse seu poder hegemônico, pois continuava a ser a moeda internacional por excelência (a mais utilizada para celebrar compras de produtos no mercado internacional e para honrar contratos dos mercados financeiros). Na seqüência, o poderio financeiro americano, através de seu Estado Nacional, passou a adotar as medidas liberalizantes aludidas no texto acima, promovendo a derrocada final do sistema de Bretton Woods, o qual, enquanto funcionou, permitiu que as economias capitalistas vivessem um período de grande prosperidade econômica, de pleno emprego e de redução das desigualdades de renda, notadamente nos países europeus. Cf., para maiores detalhes, Mattos (2001). 
aumentado expressivamente sua taxa de juros, promovendo aumento da rentabilidade do capital financeiro, queda dos investimentos produtivos e recessão em todo o mundo capitalista. O que se observou, a partir dos anos 1980, foi um aumento da instabilidade financeira internacional, desaceleração das taxas de crescimento econômico e uma corrida tecnológica em escala ampliada, com as empresas buscando alternativas para competir em uma economia mundial cada vez mais interligada pela expansão do comércio e pelos fluxos financeiros. Os resultados, do ponto de vista social e do desenvolvimento econômico, foram decepcionantes, ao contrário do que apregoavam os teóricos liberais.

As principais mudanças ocorridas no processo de globalização impulsionado a partir do final dos anos 1970 início dos anos 1980, segundo os autores filiados ao pensamento econômico crítico (entendido aqui, a grosso modo, como os autores que não se filiam à corrente liberal ou neoliberal do pensamento econômico), foram as seguintes:

a) aumento dos fluxos de capitais financeiros de curto prazo que transitam entre os mercados financeiros dos principais países do mundo capitalista, quer sejam os países desenvolvidos, os recentemente convertidos ao capitalismo (países do antigo bloco socialista, liderado pela então URSS) ou os países do chamado Terceiro Mundo (que, muitas vezes, assim como alguns dos antigos países socialistas, passam a ser chamados pelos mercados financeiros e pela imprensa de "países emergentes");

b) ampliação dos fluxos de Investimentos Diretos Externos (IDE), cujo estoque cresceu mais, em média, do que os respectivos produtos internos brutos dos principais países do mundo (CHESNAIS, 1996);

c) ampliação também do volume de exportações, embora com velocidade menor do que o crescimento dos fluxos de capitais financeiros e dos fluxos de IDE, mas ainda maiores do que as variações médias do produtos internos brutos dos principais países capitalistas do mundo (HIRST; THOMPSON, 1999);

d) concentração da maior parte dos IDE e dos negócios em fusões e aquisições de novas empresas no bloco dos países mais desenvolvidos (ou seja, os pertencentes à tríade - EUA, Japão e Europa), conforme mostra Chesnais (1996), ao contrário do que poderia parecer ao senso comum de exaltação ao processo de globalização;

e) ampliação da rapidez da incorporação dos avanços tecnológicos da microeletrônica nos processos industriais, promovendo mudanças importantes nas plantas produtivas das principais empresas e nos seus respectivos processos de trabalho (COUTINHO, 1995);

f) redução acelerada de custos de transportes e comunicações, com efeitos significativos sobre as estratégias de produção e comercialização das empresas;

g) a redução dos custos de transportes e comunicações amplia e estimula o comércio internacional, inclusive o comércio intra-firmas, pois as grandes empresas passam a poder produzir diferentes partes de seus produtos finais em diferentes países, usufruindo das vantagens de custos oferecidas por cada um deles (KOZUL-WRIGHT, 1995);

h) o novo paradigma tecnológico promove não apenas um peso crescente do complexo eletrônico, mas também possibilita a crescente automação integrada flexível nas plantas produtivas, que promovem, por sua vez, uma intensa mudança nos processos de trabalho, exigindo ao mesmo tempo maior qualificação e maior flexibilidade da mão-de-obra em suas tarefas;

i) os processos de fusões e aquisições entre grandes complexos empresarias, notadamente nas áreas farmacêutica, aeroespacial, química, têxtil, automobilística, eletroeletrônica e empresas de Tecnologia da Informação e da 
Comunicação, entre as principais, faz-se necessária para enfrentar a cada vez mais acirrada concorrência capitalista, submetida a crescente internacionalização;

j) as economias capitalistas têm crescimento de seu produto interno bruto, a partir dos anos 1980, em escala menos acelerada do que haviam presenciado nos anos 1950 e 1960; isso acirra a concorrência entre as empresas pelos mercados de vendas de produtos, pois muitas vezes o aumento das vendas se faz avançando sobre a demanda das empresas concorrentes (nos mercados nacionais ou internacionais), pois a era da globalização, ao contrário do que muitos imaginam, tem sido uma era de relativa estagnação econômica na maioria dos países do mundo (GREIDER, 1997);

k) a acumulação capitalista no setor financeiro tem sido mais acelerada do que na esfera produtiva (CHESNAIS, 1996a), o que coloca enormes dificuldades para a ampliação do estoque de empregos nos mercados de trabalho dos principais países capitalistas (MATTOS, 2001).

As características acima citadas são resultado de importantes transformações ocorridas nos últimos 30 anos na ordem internacional. Essas transformações abarcam aspectos econômicos, sociais, geopolíticos e ideológicos que moldaram a ordem mundial com a atual configuração, fundada, conforme pretendemos mostrar a seguir, em crescentes assimetrias entre Nações ${ }^{16}$ e dentro delas.

No campo ideológico, as transformações foram solidificadas pelas eleições de $\mathrm{M}$. Thatcher e de R. Reagan, respectivamente em 1979, no Reino Unido, e em 1980, nos EUA e representaram a adoção de medidas liberalizantes nos mercados de trabalho, de produtos e nas finanças. Destacadamente, as principais transformações ocorreram no mundo das finanças, que foi alvo de um intenso processo de desregulamentação dos fluxos internacionais de capitais, que acabaram com os controles que haviam sido construídos consensualmente no pós-guerra como forma de preservar os Estados Nacionais dos efeitos maléficos dos movimentos de capitais especulativos, que colocariam obstáculos à realização de políticas macroeconômicas voltadas aos objetivos do pleno emprego (conforme explicado acima). O triunfo dos ideais liberais, do Indivíduo sobre o Social, do Mercado sobre a Política, do Privado sobre o Público, referendaram as transformações promovidas pela maior potência financeira do mundo e por sua principal aliada na Europa.

A revolução ocorrida no campo tecnológico, que promoveu drástica redução nos custos dos transportes e nas comunicações (Tabela 1), impulsionou o processo de globalização produtiva e financeira, viabilizando a estratégia determinada politicamente pelas grandes potências.

Nesse contexto, o Mundo do Trabalho sofre as mais nefastas conseqüências, reveladas pela ampliação das taxas de desemprego, pela redução ou estagnação dos salários reais (MATTOS, 2001) e pela queda de participação dos salários na renda nacional na maior parte dos países (KAPSTEIN, 1999). Ainda é importante destacar que o processo de liberalização financeira e a ampliação das taxas reais de juros promovidas pelos EUA no final da década de 1970 início da década de 1980, colocaram uma enorme pressão sobre os países da periferia capitalista (América Latina, África, Oriente Médio e sudeste da Ásia), que foram castigados por pesados encargos de suas dívidas externas e conseqüente interrupção da trajetória de cresci-

\footnotetext{
16 Dados das N ações Unidas (PNUD) revelam que, em 1960, a renda média per capita dos 20\% dos habitantes mais ricos do planeta era 30 vezes maior do que a renda média dos 20\% mais pobres; em 1997, essa diferença já havia crescido para 74 vezes. O Relatório Anual de 1997 da UNCTAD revela que, nos países latino-americanos, a renda per capita, em 1979, equivalia a cerca de $36 \%$ da renda per capita dos países ricos; em 1995, equivalia a apenas $25 \%$. A concentração da renda na maior parte dos países desenvolvidos também foi significativa nas últimas décadas, conforme apontam dados da Tabela 3.
} 
Tabela 1. Custos de transportes aéreos, de chamadas telefônicas e de computadores 1930-1990.

\begin{tabular}{lccc}
\hline Ano & $\begin{array}{c}\text { Custo médio do } \\
\text { transporte aéreo } \\
\text { por passageiro/milha }\end{array}$ & $\begin{array}{c}\text { Custo de uma chamada } \\
\text { Telefônica de 3 min. } \\
\text { N. York para Londres }\end{array}$ & $\begin{array}{c}\text { Deflator de preço de } \\
\text { computador } \\
(1990=1000)\end{array}$ \\
\hline 1930 & 0,68 & 244,65 & n.d. \\
1940 & 0,46 & 188,51 & n.d. \\
1950 & 0,30 & 53,2 & n.d. \\
1960 & 0,24 & 45,86 & 125.000 \\
1970 & 0,16 & 31,58 & 19.474 \\
1980 & 0,10 & 4,80 & 3.620 \\
1990 & 0,11 & 3,32 & 1.000 \\
\hline
\end{tabular}

Fonte: Gary Hufbauer, "World Economic Integrations: The Long View”; International Economic Insights, vol. 11 (May-June, 1991). Nota: (*) Valores em dólares de 1990.

Tabela 2. Performance Econômica Comparativa no Sul.

\begin{tabular}{lcccccc}
\hline & 1938 & 1948 & 1960 & 1970 & 1980 & 1988 \\
\hline 1. América Latina & 19,5 & 14,4 & 16,7 & 15,5 & 19,8 & 10,6 \\
& $(31,1)$ & $(38,3)$ & $(45,7)$ & $(53,7)$ & $(63,8)$ & $(72,9)$ \\
1.1 Excluindo Brasil & 23,8 & 16,2 & 19,6 & 17,3 & 21,1 & 9,7 \\
& $(19,7)$ & $(24,2)$ & $(28,1)$ & $(33,0)$ & $(40,0)$ & $(45,3)$ \\
2. Oriente Médio e Norte da África & - & - & 11,5 & 8,1 & 11,1 & 7,1 \\
& - & - & $(19,6)$ & $(22,5)$ & $(27,5)$ & $(32,0)$ \\
2.1 Turquia e Egito & 14,9 & 13,0 & 12,8 & 7,7 & 8,1 & 5,6 \\
& $(9,8)$ & $(10,9)$ & $(12,9)$ & $(14,8)$ & $(17,5)$ & $(19,9)$ \\
3. África Subsaariana & & & & & & \\
3.1 Ocidental e Oriental & - & - & 3,6 & 3,4 & 4,7 & 1,6 \\
& - & - & $(36,8)$ & $(42,3)$ & $(51,7)$ & $(65,1)$ \\
3.2 Sul e Central & 25,2 & 18,3 & 10,5 & 11,3 & - & 6,1 \\
& $(6,9)$ & $(7,6)$ & $(10,1)$ & $(11,4)$ & - & $(16,1)$ \\
4. Sul da África & 8,2 & 7,5 & 3,6 & 2,8 & 2,0 & 1,8 \\
& $(109,6)$ & $(123,0)$ & $(131,6)$ & $(149,1)$ & $(173,4)$ & $(200,3)$ \\
5. Sudeste da Ásia & - & - & 6,6 & 3,8 & 5,7 & 3,7 \\
5.1 Indonésia e Filipinas & - & - & $(38,4)$ & $(43,8)$ & $(52,0)$ & $(58,9)$ \\
& $(24,1)$ & - & $(29,5)$ & $(33,1)$ & $(39,2)$ & $(44,8)$ \\
\hline
\end{tabular}

Fonte: Banco Mundial (principalmente) citado por Arrighi (1995), in E. Sader (org.) "O Mundo depois da queda".

Notas: (1) os números representam PNB per capita de país dividido pelo PNB per capita do núcleo orgânico do capitalismo multiplicado por 100 .

Entre parênteses, população do país como percentual da população total do núcleo orgânico do capitalismo (média entre EUA, Europa Ocidental e Austrália).

Agregado 1: Argentina, Bolívia, Brasil, Chile, Colômbia, República Dominicana, Equador, El Salvador, Jamaica, México, Paraguai, Peru e Venezuela.

Agregado 2: Argélia, Egito, Líbia, Sudão, Síria e Turquia.

Agregado 3.1: Benin, Burundi, Camarões, Chade, Etiópia, Costa do Marfin, Quênia, Madagascar, Malaui, Mali, Mauritânia, Moçambique, Nigéria, Ruanda, Senegal, Somália, Tanzânia, Alto Volta.

Agregado 3.2: África do Sul, Zaire, Zâmbia, Zimabábue.

Agregado 4: Bangladesh, Índia, Paquistão e Sri Lanka.

Agregado 5: Indonésia, Malásia, Filipinas, Tailândia e Cingapura. 
mento econômico que vinham trilhando desde os anos 1950 até o final dos anos $1970^{17}$. Isso provocou, a partir da década de 1980, uma ampliação da desigualdade mundial da renda quando medida pela renda per capita dos países, conforme aponta a Tabela 2, na qual a renda per capita de cada país ou cada continente é dada como percentual da renda per capita de um conjunto de países tomados como o núcleo desenvolvido do capitalismo (EUA, Europa Ocidental e Austrália) ${ }^{18}$.
Já as décadas mais recentes foram marcadas por um processo de concentração pessoal da renda, conforme mostram dados de alguns dos principais países capitalistas (Tabela 3).

E, finalmente, os dados da Tabela 4 deixam claro que a distribuição pessoal da renda, segundo extratos ( $20 \%$ cada) do conjunto da população mundial, tem sofrido um processo de concentração nas últimas décadas.

Tabela 3. Distribuição familiar da renda por estratos, dos países selecionados.

\begin{tabular}{|c|c|c|c|c|c|c|}
\hline \multirow{2}{*}{ Países e Anos } & \multicolumn{6}{|c|}{ Parcela da renda total apropriada pelos estratos de rendimentos (em \%) } \\
\hline & $\begin{array}{c}20 \% \\
\text { Inferiores }\end{array}$ & $\begin{array}{l}\text { Segundo } \\
\text { Quintil }\end{array}$ & $\begin{array}{l}\text { Terceiro } \\
\text { Quintil }\end{array}$ & $\begin{array}{l}\text { Quarto } \\
\text { Quintil }\end{array}$ & $\begin{array}{c}20 \% \\
\text { Superiores }\end{array}$ & $\begin{array}{c}10 \% \\
\text { Superiores }\end{array}$ \\
\hline \multicolumn{7}{|l|}{ Reino Unido } \\
\hline 1973 & 6,3 & 12,6 & 18,4 & 23,9 & 38,8 & 23,5 \\
\hline 1979 & 7,0 & 11,5 & 17,0 & 24,8 & 39,7 & 23,4 \\
\hline 1988 & 4,6 & 10,0 & 16,8 & 24,3 & 44,3 & 27,8 \\
\hline \multicolumn{7}{|l|}{ França } \\
\hline 1970 & 4,3 & 9,8 & 16,3 & 22,7 & 46,9 & 30,4 \\
\hline 1975 & 5,5 & 11,5 & 17,1 & 23,7 & 42,2 & 26,4 \\
\hline 1989 & 5,6 & 11,8 & 17,2 & 23,5 & 41,9 & 26,1 \\
\hline \multicolumn{7}{|l|}{ Itália } \\
\hline 1969 & 5,1 & 10,5 & 16,2 & 21,7 & 46,5 & 30,9 \\
\hline 1977 & 6,2 & 11,3 & 15,9 & 22,7 & 43,9 & 28,1 \\
\hline 1986 & 6,8 & 12,0 & 16,7 & 23,5 & 41,0 & 25,3 \\
\hline \multicolumn{7}{|l|}{ Japão } \\
\hline 1969 & 7,9 & 13,1 & 16,8 & 21,7 & 41,0 & 27,2 \\
\hline 1979 & 8,7 & 13,2 & 17,5 & 23,1 & 37,5 & 22,4 \\
\hline \multicolumn{7}{|l|}{ EUA } \\
\hline 1972 & 4,5 & 10,7 & 17,3 & 24,7 & 42,8 & 26,6 \\
\hline 1980 & 5,3 & 11,9 & 17,9 & 25,0 & 39,9 & 23,3 \\
\hline 1985 & 4,7 & 11,0 & 17,4 & 25,0 & 41,9 & 25,0 \\
\hline \multicolumn{7}{|l|}{ Suécia } \\
\hline 1972 & 6,6 & 13,1 & 18,5 & 24,8 & 37,0 & 21,3 \\
\hline 1981 & 7,4 & 13,1 & 16,8 & 21,0 & 41,7 & 28,1 \\
\hline
\end{tabular}

Fonte: Banco Mundial (vários anos).

170 Brasil é um dos melhores exemplos dessa reversão: na década de 70, seu PIB cresceu a taxas médias anuais reais de cerca de $8 \%$, enquanto que, nas décadas de 80 e de 90 , a taxa média anual real sequer atingiu os $3 \%$.

${ }^{18}$ Artigo publicado em janeiro de 2002, no The American Prospect, de autoria de Christian Weller e Adam Hersh, revela que, em 1988, a renda mediana nos $10 \%$ dos países mais ricos do planeta era 77 vezes maior do que a renda mediana dos $10 \%$ mais pobres; em 1999, essa diferença, segundo os autores, havia subido para 122 vezes. 
Os dados apresentados nesta primeira seção revelam o mito que representa a afirmação segundo a qual o capitalismo da Era da Informação e da Globalização Econômica promove uma convergência de renda entre os diferentes países. Pelo contrário, os dados revelam que a globalização atual é sinônimo de assimetria e de desigualdade. O processo de globalização, promovido pela atuação dos Estados Nacionais dos países desenvolvidos, que definem as "regras do jogo" da ordem financeira internacional, impulsiona as enormes desigualdades já existentes no mundo.

Nesse contexto de ampliação das assimetrias, as novas tecnologias não são as responsáveis pelos resultados apresentados, que têm origem em transformações de natureza política e econômico/financeira. A redução dos custos de transportes e de comunicações sem dúvida coloca a perspectiva da acumulação de capital em outra dimensão, quando analisadas as interferências do tempo e do espaço nas estratégias das empresas. Mas, não é pelo papel exercido pelas novas tecnologias que devemos interpretar os resultados socioeconômicos aqui apresentados. Estão duplamente equivocados os que atribuem às chamadas novas tecnologias um papel positivo, relacionado a uma suposta integração mundial e redução dos níveis de disparidade entre os países e dentro deles.

Conforme apontamos, não houve essa redução de desigualdade, mas uma ampliação das mesmas. Não podemos, porém, cair no mesmo erro, e atribuir às novas tecnologias os resultados decepcionantes observados. Os mesmos se devem à natureza política e financeira do processo de globalização ocorrido nas décadas mais recentes. Essa questão não foi exaustivamente analisada aqui, pois foge aos objetivos do estudo. Mas, é preciso deixar claro que o chamado "determinismo tecnológico" não deve ser colocado como explicação para as alterações ocorridas nas formas de apropriação da renda e da riqueza pelos países e pelos seus respectivos trabalhadores.

Na próxima seção, analisaremos alguns dados referentes ao Brasil. A seguir, na terceira seção, tentaremos apresentar explicações e hipóteses para sustentar o argumento segundo o qual as desigualdades econômicas tendem a ampliar as desigualdades de acesso à inclusão digital, a qual, por sua vez, também amplia as diferenças de oportunidades profissionais e econômicas entre as pessoas e entre os países.

\section{Distribuição da renda e exclusão digital no Brasil}

Uma das principais características da economia e sociedade brasileiras é seu elevado grau de desigualdade de renda e de riqueza. Esse fenômeno pode ser medido tanto pela distribuição funcional da renda (ou seja, repartição da renda nacional entre salários e lucros), quanto pela distribuição pessoal da renda (distribuição da

Tabela 4. Distribuição da renda por estratos do total da população mundial.

\begin{tabular}{lccccccc}
\hline ESTRATOS & 1960 & 1965 & 1970 & 1975 & 1980 & 1985 & 1990 \\
\hline Q1 & 0,048 & 0,042 & 0,043 & 0,043 & 0,042 & 0,045 & 0,046 \\
Q2 & 0,059 & 0,051 & 0,049 & 0,048 & 0,051 & 0,060 & 0,062 \\
Q3 & 0,082 & 0,076 & 0,071 & 0,066 & 0,067 & 0,072 & 0,071 \\
Q4 & 0,206 & 0,210 & 0,216 & 0,239 & 0,234 & 0,216 & 0,200 \\
Q5 & 0,606 & 0,621 & 0,621 & 0,606 & 0,605 & 0,607 & 0,621 \\
\hline
\end{tabular}

Fonte: Park (1997). 
renda pessoal do trabalho segundo estratos da pirâmide distributiva brasileira).

Mostra que a concentração funcional da renda no Brasil é elevadíssima e tem aumentado nas últimas décadas ${ }^{19}$ (Tabela 5).

Os dados (Tabela 6) mostram que a distribuição pessoal da renda do trabalho é extremamente concentrada no Brasil e que, nos últimos anos, tem mantido praticamente inalterado este padrão distributivo.

Passando agora ao que se refere ao objetivo principal deste trabalho, vamos analisar o Quadro 1, que apresenta dados de recente trabalho desenvolvido na Fundação Getúlio Vargas (FGV) do Rio de Janeiro (MAPA..., 2003), que procura descrever indicadores de inclusão digital no Brasil. Utilizando dados do Censo Demográfico do ano 2000, os técnicos da FGV (RJ) montaram diversas tabelas e quadros. O resultado-síntese está apresentado no quadro abaixo (Quadro 1). Neste quadro, a população total do Brasil é distribuída segundo situação de domicílio, cor ou raça, e, por fim, segundo a contribuição para a Previdência ${ }^{20}$ (coluna à esquerda).

Tabela 5. Evolução da distribuição funcional da renda brasileira parcela da renda do trabalho na renda nacional (em \%).

\begin{tabular}{lllllllll}
\hline Renda do Trabalho & 1949 & 1959 & 1970 & 1980 & 1991 & 1994 & 1998 & $1999^{*}$ \\
\hline Em \% & 56,6 & 55,5 & 52,0 & 50,0 & 49,0 & 46,0 & 42,0 & 41,3 \\
\hline
\end{tabular}

Fonte: FIBGE.

Nota: $\left(^{*}\right)$ Estimativa.

Tabela 6. Distribuição pessoal da renda do trabalho $\left(^{*}\right)$. Brasil 1988-1999.

\begin{tabular}{lrrrrrrrrrr}
\hline & \multicolumn{1}{c}{ (em \% da renda total do trabalho) } \\
\hline Grupo de renda & 1988 & 1989 & 1990 & 1992 & 1993 & 1995 & 1996 & 1997 & 1998 & 1999 \\
\hline Os 10\% mais pobres & 0,6 & 0,6 & 0,8 & 0,8 & 0,7 & 1,1 & 1,2 & 1,1 & 1,2 & 1,2 \\
Os 20\% mais pobres & 2,0 & 2,0 & 2,4 & 2,8 & 2,7 & 3,3 & 3,4 & 3,3 & 3,5 & 3,6 \\
Os 50\% mais pobres & 11,1 & 10,4 & 11,2 & 14,1 & 12,8 & 13,0 & 13,0 & 13,1 & 13,5 & 13,9 \\
Os 10\% mais ricos & 51,2 & 53,2 & 49,7 & 46,1 & 49,8 & 48,2 & 47,9 & 47,6 & 47,5 & 46,8 \\
Os 5\% mais ricos & 37,3 & 39,4 & 35,8 & 33,0 & 36,6 & 34,6 & 34,1 & 34,0 & 34,0 & 33,4 \\
O 1\% mais rico & 15,2 & 17,3 & 14,6 & 13,7 & 16,0 & 13,9 & 13,5 & 13,7 & 13,7 & 13,0 \\
\hline
\end{tabular}

Fonte: IBGE. PNAD citada por Anuário... (2001).

Nota: $\left({ }^{*}\right)$ rendimento mensal de todos os trabalhos dos ocupados com rendimento do trabalho.

OBS.: em 1991, não houve PNAD; em 1994, dados não disponíveis.

\footnotetext{
19 Em poucas palavras, podemos afirmar que a distribuição funcional da renda representa a repartição da renda nacional entre lucros e salários. 0 caso brasileiro é um dos mais marcantes em termos de concentração de renda em favor do capital. Essa concentração funcional da renda se desdobra, invariavelmente, em al ta concentração pessoal da renda do trabal ho (MATTOS, 1995). Tanto no caso da distribuição funcional, quanto no da distribuição pessoal da renda, o Brasil é o país de maiores graus de concentração de renda no mundo (ANUÁRIO..., 2001).

20 No quadro do trabalho original (MAPA..., 2003), estão também incluídas informações referentes a religião, natureza da última união e estado civil da população. Essas informações estão excluídas do Quadro 1, elaborado para este artigo, pois não permitem que delas se depreendam conclusões relacionadas aos objetivos deste trabal ho.
} 
Na coluna à direita, a população que tem acesso direto à Internet (os chamados incluídos digitais) é distribuída segundo os mesmos critérios da distribuição do conjunto da população. A comparação entre as colunas revela uma pronunciada diferença entre a distribuição do conjunto da população e a distribuição dos incluídos digitais. Várias conclusões podem ser retiradas dos dados apresentados: (a) existe proporcionalmente maior inclusão digital nas áreas urbanizadas; (b) segundo cor ou raça, a população branca é proporcionalmente mais incluída do que os pretos, os pardos e os indígenas; (c) existe uma pronunciada diferença nas duas colunas de distribuição da população de ascendência asiática, revelando relativamente elevado grau de inclusão digital entre essas pessoas $^{21}$; (d) por fim, no que se refere à contri- buição para a Previdência, também se pode constatar uma pronunciada desproporção distributiva, que sugere maior inclusão dos trabalhadores que contribuem para a Previdência, ou seja, os dados revelam que as pessoas cujo vínculo empregatício é mais estável caracterizam-se por graus bem mais elevados de inclusão digital do que as outras. Essas observações sugerem que os indicadores brasileiros de exclusão digital reproduzem, muitas vezes em escala ampliada, os de exclusão social. Conforme ocorre em todos os países, as áreas urbanizadas são caracterizadas por apresentarem maiores rendimentos (a tabela não mostra isso, mas a literatura sobre o tema não deixa margem a dúvidas) do que as áreas não urbanizadas. E, no Quadro 1, os dados revelam que a população que habita em áreas urbani-

Quadro 1. Distribuição da população total e da população incluída digitalmente. Brasil, 2000.

\begin{tabular}{|c|c|c|c|c|}
\hline & \multicolumn{2}{|c|}{ População Total } & \multicolumn{2}{|c|}{ Incluídos Digitais } \\
\hline & População & Participação (em \%) & População & Participação (em \%) \\
\hline Total & 169.872 .856 & 100,00 & 17.328 .185 & 100,00 \\
\hline \multicolumn{5}{|l|}{ Situação de Domicílio } \\
\hline Área urbanizada & 135.615 .944 & 79,83 & 16.849 .493 & 97,24 \\
\hline Área não-urbanizada & 1.250 .580 & 0,74 & 75.434 & 0,44 \\
\hline Outros $\left({ }^{*}\right)$ & 33.006 .332 & 19,43 & 403.258 & 2,32 \\
\hline \multicolumn{5}{|l|}{ Cor ou raça } \\
\hline Branca & 91.298 .042 & 53,74 & 13.822 .499 & 79,77 \\
\hline Preta & 10.554 .336 & 6,21 & 419.185 & 2,42 \\
\hline Amarela & 761.583 & 0,45 & 317.295 & 1,83 \\
\hline Parda & 65.328 .092 & 38,45 & 2.654 .497 & 15,32 \\
\hline Indígena & 734.127 & 0,43 & 27.286 & 0,16 \\
\hline Outras & 1.206 .675 & 0,71 & 87.424 & 0,5 \\
\hline \multicolumn{5}{|c|}{ Contribuição para a Previdência } \\
\hline Contribui & 6.198 .855 & 3,65 & 1.736 .245 & 10,18 \\
\hline Não contribui & 26.880 .461 & 15,82 & 1.856 .011 & 10,71 \\
\hline Ignorado & 136.793 .539 & 80,53 & 13.708 .929 & 79,11 \\
\hline
\end{tabular}

Fonte: CPS/FGV: processamento de dados do Censo Demográfico 2000/IBGE. Adaptado por este autor. Nota: $\left(^{*}\right)$ inclui diversos tipos de aglomerados rurais e de áreas rurais de extensão urbana.

${ }^{21}$ Do conjunto da população brasileira segundo o Censo Demográfico de 2000 (169.872.856 habitantes), há 17.328.185 que estão digitalmente incluídos, ou seja, cerca de 10,2\%. No caso das pessoas de origem asiática, cerca de $42 \%$ estão digitalmente incluídas, ou seja, uma proporção bem superior à média brasileira. Entre a população branca, cerca de 15\% estão digitalmente incluídos. 
zadas, no Brasil, tem proporcionalmente maior acesso direto à Internet do que a que habita em áreas não-urbanizadas. Da mesma forma, sabese que, no Brasil, a população branca e os descendentes de asiáticos têm renda média superior à da população negra ${ }^{22}$ ou parda e essa desigualdade está também reproduzida nos indicadores de inclusão digital: a proporção de pessoas da etnia branca no conjunto das digitalmente incluídas é expressivamente maior do que a proporção de pessoas desta mesma etnia no conjunto da população brasileira. $O$ mesmo ocorre entre os descendentes de asiáticos.

Finalmente, é forçoso destacar as desigualdades regionais existentes nos indicadores de exclusão digital no Brasil. Como se sabe, a concentração regional da renda é também uma marca da sociedade brasileira e a mesma também se expressa em elevadas assimetrias no que se refere ao acesso ao uso de computadores (Tabela 7). O Distrito Federal e os Estados mais ricos da federação brasileira revelam graus muito mais elevados de utilização de computadores do que os estados mais pobres. As diferenças existentes podem ser melhor avaliadas quando comparadas à média nacional, revelando de forma mais clara as assimetrias regionais que caracterizam a sociedade brasileira também no aspecto da inclusão digital. Compreender esse fenômeno é fundamental, pois, assim como no caso das desigualdades pessoais da renda, a infoexclusão pode ampliar as desigualdades regionais e impulsionar as diferenças setoriais de renda ${ }^{23}$. Nas palavras de Lévy (1999, p.175-176), "as performances industriais e comerciais das companhias, das regiões, das grandes zonas geopolíticas, são intimamente correlacionadas a políticas de gestão do saber"24.

Para concluir esta seção, é preciso sublinhar que a base de dados sobre exclusão/inclusão digital no Brasil é ainda bastante precária, não permitindo tirar conclusões muito importantes sobre o tema. O trabalho elaborado pela FGV, RJ representa uma iniciativa importante, mas que ainda se revela pouco conclusiva. Temos que levar em conta, ainda, que a exclusão digital é interpretada apenas em termos quantitativos, tanto na literatura nacional, quanto mesmo na internacional, sendo ainda incipientes as tentativas de avaliar de forma qualitativa a inclusão/exclusão digital - o que implicaria definir alguns conceitos que pudessem medir a capacidade cognitiva dos que, para todos os efeitos, entram nas estatísticas como "digitalmente

22 Em Anuário... (2001, p.143) são apresentados quadros comparativos dos rendimentos dos homens e das mulheres nãonegros com os respectivos rendimentos dos homens e das mulheres negras nas Regiões Metropolitanas (RM) de São Paulo, de Salvador, do Distrito Federal, de Belo Horizonte, de Porto Alegre e de Recife. Em todos os exemplos regionais os rendimentos médios dos trabalhadores negros (tanto dos homens, quanto das mulheres) é expressivamente inferior aos respectivos rendimentos dos homens não-negros e das mulheres não-negras. A maior diferença entre os rendimentos dos homens não-negros e dos homens negros ocorre na RM de Salvador, em que o rendimento médio dos negros equivale a $50,6 \%$ do rendimento dos homens não-negros. A menor diferença de rendimentos entre os homens das diferentes etnias ocorre na RM de Porto Alegre, mas mesmo assim a diferença é expressiva: os negros têm rendimento cerca de $27,0 \%$ menor. Entre as mulheres a situação se repete: na RM de Salvador, o rendimento médio das mulheres negras é cerca de 53,0\% do rendimento das mulheres não-negras e a menor diferença é encontrada no Distrito Federal, mas mesmo assim com diferença expressiva: o rendimento médio das mulheres negras equivale apenas a cerca de $73,0 \%$ do rendimento das mulheres não-negras. No Brasil, é muito mais expressiva a discriminação salarial por raça (ou etnia) do que a discriminação por gênero.

${ }^{23} \mathrm{~A}$ informação tem papel cada vez mais decisivo, no âmbito empresarial, como recurso produtivo nos processos de maior valor adicionado dos setores de ponta do capitalismo mundial. A concorrência inter-capitalista entre empresas de mesmo setor de atividade se manifesta em grande medida pela busca e pela manipulação contínuas da informação e de sua transformação em conhecimento e inovação.

24 Não só concordamos com Lévy (1999), como também gostaríamos de acrescentar que o domínio das tecnologias da informação e das áreas de fronteira do conhecimento tecnológico representam, para as Nações, fatores fundamentais e decisivos de soberania e segurança nacional. Não vamos nos aprofundar nesse argumento, pois o mesmo foge aos objetivos deste trabalho. 
incluídos". Portanto, tratar-se-ia de avaliar, de forma mais acurada, a capacidade cognitiva dos infoincluídos, o que implica, em grande medida, medir a capacidade dessas pessoas em transformar informação em conhecimento.

\section{As Tecnologias da Informação e da Comunicação (TIC) e as novas tendências à desigualdade}

O se pôde concluir até aqui é que o processo de globalização tende a gerar desigualdades entre as pessoas dentro dos países e também desigualdade entre os países. Além disso, deve-se levar em conta, conforme salienta Proenza (2003), que o próprio desenvolvimento das TIC, ocorrido no espaço da globalização tal qual caracterizada na primeira seção deste artigo, tende também a criar novos elementos que contribuem para ampliar as desigualdades econômicas. O autor apresenta dois quadros (Quadros 2 e 3, abaixo reproduzidos) que sustentam seu argumento. No que se refere aos indicadores de infoexclusão em nível mundial, os resultados são apresentados no Quadro 2. Os dados deste quadro revelam uma acentuada diferença de inclusão digital entre os países. A primeira coluna, com indicadores que reúnem apenas os usuários ligados diretamente à rede (exclui, portanto, os usuários que a acessam em telecentros, cabines públicas, etc.), revelam que o conjunto América Latina/Caribe apresenta baixos níveis de conexão à internet, embora com graus diferenciados dentro dessa região. $O$ mesmo pode-se afirmar com relação ao norte da África e à Ásia e países do Pacífico (neste último caso, com a notável exceção da Coréia do Sul, país que se caracterizou, nas últimas décadas pelos seus elevadíssimos investimentos em educação e em formação profissional ${ }^{25}$ ). A mostra de países da Organização de Cooperação e Desenvolvimento Econômico (OCDE) (grupo dos países mais desenvolvidos do mundo) apre-

Tabela 7. Unidades da Federação brasileira com maior e com menor grau de inclusão digital.

\begin{tabular}{lccc}
\hline & $\begin{array}{c}\text { Moradores em domicílios } \\
\text { Particulares Permanentes }\end{array}$ & $\begin{array}{c}\text { Acesso a } \\
\text { microcomputador }\end{array}$ & $\begin{array}{c}\text { Proporção (em \%) moradores com } \\
\text { acesso/total de moradores }\end{array}$ \\
\hline Brasil & 168.450 .489 & 17.328 .185 & 10,29 \\
Unidades da Federação & & & \\
Maior Inclusão Digital & 2.035 .459 & 485.820 & 23,87 \\
Distrito Federal & 36.719 .202 & 6.603 .586 & 17,89 \\
São Paulo & 14.289 .735 & 2.217 .769 & 15,51 \\
Rio de Janeiro & 5.319 .120 & 654.177 & 12,30 \\
Santa Catarina & 9.471 .919 & 1.097 .529 & 11,59 \\
Paraná & & & 2,05 \\
Menor Inclusão Digital & 5.621 .913 & 115.211 & 2,78 \\
Maranhão & 2.832 .095 & 78.811 & 2,76 \\
Piauí & 1.143 .283 & 31.533 & 3,42 \\
Tocantins & 552.016 & 18.881 & 3,60 \\
Acre & 2.797 .246 & 100.664 & \\
Alagoas & & & \\
\hline
\end{tabular}

Fonte: Mapa..., (2003).

${ }^{25}$ Além de ter desenvolvido, como política de Estado, um programa amplo de "informatização" que levou o índice de infoinclusão de 2\% da população, em 1995, para 65\% em 2001, conforme Park (2001) citado por Proenza (2003). 
senta, como seria de se esperar, expressivos níveis de conexão à Internet, ressalvadas algumas diferenças também dentro deste grupo, as quais se relacionam, provavelmente, a diferenças culturais que conduzem as respectivas populações a níveis variados de entusiasmo no que se refere à adesão às novas tecnologias (vindas, na maioria dos casos, dos EUA). Nos casos de acessão a PC's, a linhas de telefonia fixa e ao uso de telefones celulares, o padrão de exclusão/ inclusão é semelhante ao caso da conexão à Internet.

No Quadro 3, são apresentados indicadores de desigualdade de renda e de níveis de pobreza para diversos países do mundo. Nota-se que há uma correspondência entre esses indicadores e os mencionados no Quadro 2. Ou seja, os países com renda per capita menor e/ou com renda mais concentrada (indicador descrito pela relação entre a parcela da renda apropriada pelos $20 \%$ mais ricos da população em relação à parcela da renda total apropriada pelo estrato dos $20 \%$ mais pobres da população) são justamente aqueles que ostentam os mais eloqüentes indicadores de infoexclusão.

Os notáveis índices de desigualdade refletem-se também na distribuição mundial do acesso digital. Fiori $(2001 a$, p.48,49) sublinha que, apesar da ampliação indiscutível do uso da Internet no mundo, ainda somente $5 \%$ da população mundial tem acesso à Internetno início do século XXI, sendo que "metade dos internautas está nos EUA. Na Finlândia, há mais servidores do que em toda a América Latina e, só em Nova York, mais do que em toda a África". Tais dados são bastante significativos da assimetria digital existente no mundo atual, notadamente se considerarmos que os EUA detêm cerca de $30 \%$ da renda mundial (Tabela
8), mas cerca de $50 \%$ dos internautas, conforme destacou Fiori (2001a) ${ }^{26}$.

Podemos ainda destacar que, dentro dos EUA, também ocorre um processo de exclusão digital, quando medido por classe de renda ou por etnia, conforme indicam as Tabelas 9 e 10, a seguir, as quais comparam os percentuais de grupos populacionais selecionados no conjunto da população e no conjunto dos chamados digitalmente incluídos.

Todos os indicadores aqui descritos e comentados parecem reforçar a nossa hipótese de que as vantagens competitivas e a desigualdade entre os países, em termos de progresso tecnológico e também em termos de acesso à educação formal e por fim também com relação à renda, representam elementos que se autoreforçam e que ampliam as distâncias entre os países (e dentro deles) no que se refere ao acesso à Internet. Ou seja, parece que a exclusão digital é ainda mais expressiva do que a exclusão social, e, provavelmente, elas se reforçam mutuamente.

Há uma vasta literatura que retrata os efeitos assimétricos do atual processo de globalização ${ }^{27}$. Mais recentemente, tem surgido também uma literatura que se debruça sobre os efeitos assimétricos provocados pelas novas Tecnologias da Informação e da Comunicação. Proenza (2003) está entre os autores que dedicaram-se a estudar os efeitos desigualitários provocados pelas Tecnologias da Informação e da Comunicação, tanto nos países desenvolvidos, quanto nos subdesenvolvidos. Segundo o autor, o desenvolvimento das TIC's tende a aumentar a desigualdade devido a, basicamente, quatro motivos:

26 Farah (2001) também destaca que os EUA concentram "quase a metade" dos internautas do mundo.

${ }^{27}$ Cf. Fiori (2001a) e (2001b), Milewski (1997), Tavares (1997) e (1998) e Mattos (2001). 
Quadro 2. Indicadores de tecnologias da informação em países selecionados em 2001, dados para cada 100 habitantes.

\begin{tabular}{|c|c|c|c|c|}
\hline Países e Continentes & Usuários de Internet & Usuários de PCs & Linhas de Telefonia fixa & Telefones Celulares \\
\hline \multicolumn{5}{|c|}{ América Latina e Caribe } \\
\hline Argentina & 8,0 & 5,3 & 21,6 & 18,6 \\
\hline Brasil & 4,6 & 6,3 & 21,7 & 16,7 \\
\hline Guatemala & 2,0 & 1,7 & 6,5 & 9,7 \\
\hline Paraguai & 1,1 & 1,1 & 5,1 & 20,4 \\
\hline Colômbia & 2,7 & 4,2 & 17,1 & 7,4 \\
\hline El Salvador & 0,8 & 2,2 & 9,3 & 12,5 \\
\hline Honduras & 0,6 & 1,2 & 4,7 & 3,6 \\
\hline Chile & 20,0 & 8,4 & 23,9 & 34 \\
\hline México & 3,5 & 6,9 & 13,5 & 20,1 \\
\hline Panamá & 3,2 & 3,8 & 14,8 & 20,7 \\
\hline Venezuela & 5,3 & 5,3 & 11,2 & 26,4 \\
\hline Costa Rica & 9,3 & 17,0 & 23,0 & 7,6 \\
\hline Nicarágua & 1,0 & 1,0 & 3,1 & 3,0 \\
\hline República Dominicana & 2,1 & n.d. & 10,8 & 12,4 \\
\hline Peru & 11,5 & 4,8 & 7,8 & 5,9 \\
\hline Equador & 2,5 & 2,3 & 10,4 & 6,7 \\
\hline Uruguai & 11,9 & 11,0 & 28,3 & 15,5 \\
\hline Bolívia & 1,4 & 2,0 & 6,0 & 8,7 \\
\hline Haiti & 0,4 & n.d. & 1,0 & 1,1 \\
\hline Jamaica & 3,8 & 5,0 & 19,7 & 26,9 \\
\hline \multicolumn{5}{|c|}{ Mostra de Países da OCDE } \\
\hline Reino Unido & 40 & 36,6 & 57,8 & 78,3 \\
\hline EUA & 49,9 & 62,3 & 52 & 44,4 \\
\hline Austrália & 37,2 & 51,7 & 66,5 & 57,8 \\
\hline Irlanda & 23,3 & 39,1 & 48,5 & 72,9 \\
\hline França & 26,4 & 33,7 & 57,4 & 60,5 \\
\hline Canadá & 43,5 & 39,0 & 65,6 & 32,0 \\
\hline \multicolumn{5}{|c|}{ Ásia e Países do Pacífico } \\
\hline China & 2,6 & 1,9 & 13,8 & 11,2 \\
\hline República da Coréia & 51,1 & 25,1 & 47,6 & 60,8 \\
\hline Indonésia & 1,9 & 1,1 & 3,7 & 2,5 \\
\hline Índia & 0,1 & 0,6 & 3,4 & 0,6 \\
\hline Bangladesh & 0,0 & 0,2 & 0,4 & 0,4 \\
\hline \multicolumn{5}{|c|}{ África (ao sul do Saara) } \\
\hline África do Sul & 7,0 & 6,9 & 11,4 & 21 \\
\hline Quênia & 1,6 & 0,6 & 1,0 & 1,6 \\
\hline Nigéria & 0,0 & 0,7 & 0,4 & 0,3 \\
\hline Senegal & 0,1 & 1,9 & 2,5 & 4,0 \\
\hline Gana & 0,2 & 0,3 & 1,2 & 0,9 \\
\hline \multicolumn{5}{|c|}{ Norte da África e Oriente Médio } \\
\hline Egito & 0,9 & 1,6 & 10,3 & 4,3 \\
\hline Marrocos & 1,3 & 1,3 & 3,9 & 15,7 \\
\hline Jordânia & 4,1 & 3,3 & 12,7 & 14,4 \\
\hline Argélia & 0,0 & 0,7 & 6,0 & 0,3 \\
\hline \multicolumn{5}{|l|}{ Europa Oriental } \\
\hline Estônia & 30,0 & 17,5 & 35,2 & 45,5 \\
\hline Hungria & 14,8 & 10,0 & 37,4 & 49,8 \\
\hline República Checa & 13,6 & 12,1 & 37,4 & 65,9 \\
\hline \multicolumn{5}{|c|}{ Mostra de Países da OCDE } \\
\hline Espanha & 18,3 & 16,8 & 43,1 & 65,5 \\
\hline Itália & 27,6 & 19,5 & 47,1 & 83,9 \\
\hline Alemanha & 36,4 & 33,6 & 63,5 & 68,3 \\
\hline Noruega & 59,6 & 50,8 & 72,0 & 82,5 \\
\hline Finlândia & 43,0 & 42,4 & 54,8 & 77,8 \\
\hline Japão & 45,5 & 34,9 & 59,7 & 57,2 \\
\hline
\end{tabular}

Fonte: Indicadores da UIT, 2001. Http://www.itu.int/ITU-D/Tic/statisTIC citados por Proenza (2003). 
Quadro 3. Percentual dos que se encontram abaixo da linha de pobreza e indicadores de renda per capita nos países, participação em porcentagem da renda apropriada pelos $20 \%$ com maiores e menores rendas.

\begin{tabular}{|c|c|c|c|c|}
\hline Países e Continentes & $20 \%$ mais baixo & $20 \%$ mais alto & $\begin{array}{c}\% \text { da população que ganha } \\
\text { menos que US } \$ 2 / \text { dia }\end{array}$ & $\begin{array}{c}\text { Renda Per Capita } \\
\text { US } \$\end{array}$ \\
\hline \multicolumn{5}{|c|}{ América Latina e Caribe } \\
\hline Argentina & n.d. & n.d. & n.d. & 11.324 \\
\hline Brasil & 2,5 & 63,8 & 17,4 & 6.317 \\
\hline Guatemala & 2,1 & 63,6 & 64,3 & 3.517 \\
\hline Paraguai & 2,3 & 62,4 & 38,5 & 4.193 \\
\hline Colômbia & 3,0 & 60,9 & 28,7 & 5.709 \\
\hline El Salvador & 3,4 & 56,5 & 51,9 & 4.048 \\
\hline Honduras & 3,4 & 58 & 68,8 & 2.254 \\
\hline Chile & 3,5 & 61 & 20,3 & 8.370 \\
\hline México & 3,6 & 58,2 & 42,5 & 7.719 \\
\hline Panamá & 3,6 & 52,8 & 25,1 & 5.016 \\
\hline Venezuela & 3,7 & 53,1 & 36,4 & 5.268 \\
\hline Costa Rica & 4,0 & 51,8 & 26,3 & 5.770 \\
\hline Nicarágua & 4,2 & 55,2 & n.d. & 4.653 \\
\hline República Dominicana & 4,3 & 53,7 & 16,0 & 4.653 \\
\hline Peru & 4,4 & 51,8 & 41,4 & 4.387 \\
\hline Equador & 5,4 & 49,7 & 52,3 & 2.605 \\
\hline Uruguai & 5,4 & 48,3 & 6,6 & 8.280 \\
\hline Bolívia & 5,6 & 48,2 & 38,6 & 2.193 \\
\hline Haiti & n.d. & n.d. & n.d. & 1.407 \\
\hline Jamaica & 7,0 & 43,9 & 25,2 & 3.276 \\
\hline \multicolumn{5}{|c|}{ Mostra de Países da OCDE } \\
\hline Reino Unido & 6,6 & 33,0 & & 20.880 \\
\hline EUA & 5,2 & 46,4 & & 30.600 \\
\hline Austrália & 5,9 & 41,3 & & 22.448 \\
\hline Irlanda & 6,7 & 42,9 & & 19.180 \\
\hline França & 7,2 & 40,2 & & 21.897 \\
\hline Canadá & 7,5 & 39,3 & & 23.725 \\
\hline \multicolumn{5}{|c|}{ Ásia e Países do Pacífico } \\
\hline China & 5,9 & 46,6 & 53,7 & 3.291 \\
\hline República da Coréia & 7,5 & 39,3 & n.d. & 14.637 \\
\hline Indonésia & 8,0 & 44,9 & 66,1 & 2.439 \\
\hline Índia & 8,1 & 46,1 & 86,2 & 2.149 \\
\hline Bangladesh & 8,7 & 42,8 & 77,8 & 1.475 \\
\hline \multicolumn{5}{|l|}{ África (ao sul do Saara) } \\
\hline África do Sul & 2,9 & 64,8 & 35,8 & 8.318 \\
\hline Quênia & 5,0 & 50,2 & 62,3 & 975 \\
\hline Nigéria & 4,4 & 55,7 & 90,8 & 744 \\
\hline Senegal & 6,4 & 48,2 & 67,8 & 1.341 \\
\hline Gana & 8,4 & 41,7 & n.d. & 1.793 \\
\hline \multicolumn{5}{|c|}{ Norte da África e Oriente Médio } \\
\hline Egito & 9,8 & 39 & 11,4 & 3.303 \\
\hline Marrocos & 6,5 & 46,6 & 7,5 & 3.190 \\
\hline Jordânia & 7,6 & 44,4 & 7,4 & 3.542 \\
\hline Argélia & 7,0 & 42,6 & 15,1 & 4.753 \\
\hline \multicolumn{5}{|l|}{ Europa Oriental } \\
\hline Estônia & 6,2 & 41,8 & 17,7 & 7.826 \\
\hline Hungria & 8,8 & 39,9 & 4,0 & 10.479 \\
\hline República Checa & 10,3 & 35,9 & n.d. & 12.289 \\
\hline \multicolumn{5}{|c|}{ Mostra de Países da OCDE } \\
\hline Espanha & 7,5 & 40,3 & & 16.730 \\
\hline Itália & 8,7 & 36,3 & & 20.751 \\
\hline Alemanha & 8,2 & 38,5 & & 22.404 \\
\hline Noruega & 9,7 & 35,8 & & 26.522 \\
\hline Finlândia & 10,0 & 35,8 & & 21.209 \\
\hline Japão & 10,6 & 35,7 & & 24.041 \\
\hline
\end{tabular}

Fonte: Indicadores da UIT, 2001. Http://www.itu.int/ITU-D/Tic/statisTIC citados por Proenza (2003). 
Tabela 8. Participação de países selecionados no PIB mundial (PIB em dólar).

\begin{tabular}{lrrrrrrrrrr}
\hline Países e G7 & 1995 & 1996 & 1997 & 1998 & 1999 & 2000 & 2001 & 2002 & 2003 & 2004 \\
\hline Estados Unidos & 25,43 & 26,21 & 28,01 & 29,75 & 30,34 & 31,32 & 32,49 & 32,53 & 30,60 & 30,76 \\
Argentina & 0,89 & 0,91 & 0,99 & 1,01 & 0,93 & 0,91 & 0,87 & 0,29 & 0,36 & 0,40 \\
Brasil & 2,42 & 2,60 & 2,72 & 2,66 & 1,71 & 1,91 & 1,64 & 1,38 & 1,43 & 1,45 \\
Canadá & 2,03 & 2,06 & 2,15 & 2,09 & 2,16 & 2,31 & 2,30 & 2,29 & 2,42 & 2,47 \\
China & 2,41 & 2,74 & 3,02 & 3,21 & 3,24 & 3,45 & 3,79 & 3,94 & 3,86 & 4,03 \\
França & 5,35 & 5,22 & 4,74 & 4,93 & 4,73 & 4,19 & 4,26 & 4,48 & 4,89 & 4,84 \\
Alemanha & 8,45 & 8,00 & 7,12 & 7,27 & 6,91 & 5,98 & 5,98 & 6,20 & 6,70 & 6,55 \\
Itália & 3,77 & 4,14 & 3,93 & 4,06 & 3,87 & 3,44 & 3,52 & 3,70 & 4,09 & 4,05 \\
Japão & 18,22 & 15,79 & 14,56 & 13,37 & 14,64 & 15,20 & 13,46 & 12,41 & 11,79 & 11,28 \\
Reino Unido & 3,90 & 3,99 & 4,47 & 4,82 & 4,78 & 4,59 & 4,61 & 4,88 & 4,96 & 4,91 \\
Países do G7 & 67,15 & 65,39 & 64,97 & 66,29 & 67,42 & 67,02 & 66,62 & 66,49 & 65,45 & 64,87 \\
\hline
\end{tabular}

Fonte: IMF Economic Outlook (vários anos).

Tabela 9. Usuários de Internet e sobre a população total dos EUA. Por grupo étnico, classe de renda e nível de educação formal, no ano 2000.

\begin{tabular}{lcc}
\hline & \% na população & \% de usuários de Internet \\
\hline Brancos & 72 & 90 \\
Afro-americanos & 14 & 2 \\
Hispânicos & 12 & 5 \\
Universitários ou pessoas de educação de nível superior & 25 & 63 \\
Renda familiar anual acima de US\$ 35.000 & 55 & 73 \\
\hline
\end{tabular}

Fonte: United... (2001).

Nota: Inclui apenas usuários de Internet e pessoas com 18 anos ou mais.

Tabela 10. Inclusão digital por extrato de renda anual EUA 2000.

\begin{tabular}{lcc}
\hline Extratos de renda & \% na população & \% de usuários de Internet \\
\hline Abaixo de US\$ 35.000 & 45 & 25 \\
De US\$ 35.000 a 49.999 & 15 & 23 \\
De US\$ 50.000 a 74.999 & 18 & 31 \\
Acima de US\$ 75.000 & 22 & 21 \\
\hline
\end{tabular}

Fonte: United... (2001).

Nota: Inclui apenas usuários de Internet e pessoas com 18 anos ou mais.

(a) no caso dos EUA, os inovadores que desenvolveram aplica-tivos de utilidade universal com benefícios extraordinários, por serem os primeiros a aproveitar o imenso mercado mundial; (b) o acelerado aumento na produtividade, que se observa nos EUA a partir da metade dos anos 1990, está bastante 
vinculado à articulação entre os computa-dores e as empresas, ocasiona-da pela explosão no uso comercial da Internet (CRANDALL; JACKSON, 2002); (c) a infra-estru-tura das TIC's é mais rentável e, portanto, mais fácil de desenvolver em áreas urbanas; isso tende a aumentar as diferenças em capacidade de produção e prestação de serviços entre as zonas rurais e urbanas; (d) cada vez mais, os mercados de trabalho exigem novas habilidades e o conhecimento da Internet e dos computadores. Os empregos na nova economia demandam horários flexíveis e são de caráter temporário, dando lugar a freqüentes períodos descontínuos de desemprego e tornando necessária a atualização das habilidades. A mão-de-obra não qualificada e de baixa produtividade passa a ser um "produto padrão" e mal pago, do qual se pode abrir mão facilmente e que está desprotegido no vaivém econômico e no desemprego, por causa do progressivo enfraquecimento dos sindicatos.

Sem entrar detalhadamente no mérito de todas as observações feitas por Proenza (2003) ${ }^{28}$, podemos considerar que seus comentários chamam a atenção para elementos que de fato representam desigualdades sob o capitalismo (como, por exemplo, as diferenças no grau de desenvolvimento de áreas rurais e urbanas, ou como as vantagens econômicas desfrutadas pelos inventores ${ }^{29}$ pioneiros enquanto os concorrentes não logram copiar as inovações). Mais do que isso, devemos destacar que, em países subdesenvolvidos, como o Brasil, marcados por acentuadas heterogeneidades estruturais ${ }^{30}$, determinadas historicamente ${ }^{31}$, a introdução das

28 Uma questão que poderia ser problematizada seria a relação entre aumento da capacidade do indivíduo em manipular as novas tecnologias da informação e da comunicação e a sua inserção no mercado de trabalho. Não podemos deixar de frisar que a questão do emprego depende, fundamentalmente, do desenvolvimento econômico dos países e/ou das regiões, não se resumindo a uma questão pessoal. O u seja, podemos afirmar, na melhor tradição do pensamento econômico keynesiano, que a expansão do emprego depende muito mais das forças de demanda por mão-de-obra nos mercados de trabalho do que das condições da oferta de mão-de-obra. Isso não impede de afirmar que cada pessoa aumenta suas possibilidades individuais de obter um emprego (qualquer emprego, não necessariamente aquele ao qual ela se habilita) quando se capacita no domínio das novas tecnologias. Mas seu êxito depende, fundamentalmente, da trajetória de crescimento econômico e das possibilidades que o mesmo abre em termos de criação de novos postos de trabalho. A tradição liberal, em oposição ao pensamento keynesiano, destaca a questão da oferta de mão-de-obra como preponderante para a geração de postos de trabalho.

${ }^{29}$ Conceito de lucros extraordinários de Schumpeter (1942)

${ }^{30}$ Aníbal Pinto (1979) cunhou o conceito de heterogeneidade estrutural, que representa as marcantes diferenças de produtividade existentes em diferentes setores produtivos da América Latina, dado que a industrialização pesada (instalação do setor produtor de bens de capitais) nesses países (e o Brasil é o melhor exemplo disso, posto que foi o país que obteve maior êxito em termos de industrialização no sub-continente) aconteceu de forma tardia, incorporando tecnologias vindas de fora, de países que já haviam passado por um longo processo de desenvolvimento capitalista nos dois séculos anteriores. Essas tecnologias vindas de fora instalam-se em países caracterizados por atividades de baixa produtividade, tanto nas atividades industriais (indústrias leves, de bens de consumo não-duráveis), quanto nas atividades rurais (muitas das quais são produção agrícola para subsistência); dessa forma, passam a conviver, no mesmo território, atividades de alta produtividade com atividades de baixa produtividade, que, muitas vezes, não foram "arrastadas" pelas atividades mais produtivas. Segundo Pinto (1979), ocorreu uma "tríplice concentração dos frutos do progresso técnico", gerando desigualdades regionais, sociais e econômicas (os mercados de trabalho reproduzem estruturas produtivas heterogêneas e geram postos de trabalho com acentuadas diferenças de remuneração).

$31 \mathrm{Na}$ mesma linha que Pinto (1979), Bravo (1979, p.89) destaca os aspectos peculiares do processo de desenvolvimento capitalista nos países da América Latina, destacando o momento histórico em que se deu a industrialização nesses países (quand o o capitalismo já estava consolidado nos países centrais e já se baseava em estruturas industriais de capital fortemente concentrado - indústrias oligopolizadas, características da Segunda Revolução Industrial) como fator determinante para a heterogeneidade estrutural existente nessas sociedades: "os países industrializados passaram por uma etapa de ativa concorrência entre um grande número de unidades produtivas e que foi, progressivamente, sendo substituída por formas oligopólicas e monopólicas que surgiram como conseqüência do próprio desenvolvimento das forças produtivas e a partir de níveis de produtividade já relativamente al tos e generalizados no conjunto do sistema. Nos países latino-americanos, 0 processo se desenvolveu de forma diferente. 0 monopólio ou o oligopólio se fizeram presentes desde os primeiros passos da industrialização, superpondo-se a condições produtivas muito atrasadas". 
novas Tecnologias da Informação e da Comunicação tende a acentuar ainda mais as assimetrias econômicas, sociais e setoriais, pois já encontram "campo fértil" nas próprias características da economia capitalista (fortemente desigual) que foi historicamente constituída.

Poderíamos destacar que, no caso específico de um país como o Brasil, onde as oportunidades de ascensão social têm se restringido bastante nos últimos 25 anos, e onde, como se sabe, há enormes diferenças de anos escolares entre as pessoas, há um outro elemento que acentua as diferenças sociais: o fator cognitivo, o qual, diga-se de passagem, não é dimensionado nas estatísticas mais usuais de exclusão digital, nem na literatura brasileira já existente sobre o tema e nem na literatura estrangeira. Ou seja, as estatísticas mais encontradiças de exclusão digital revelam apenas o número de pessoas com acesso à rede mundial de computadores, mas não conseguem avaliar a qualidade dessa inserção - mais claramente: não conseguem avaliar a capacidade de compreensão e análise das informações disponibilizadas pela Internet. Trata-se de um fator bastante subjetivo, pois ligado à formação escolar e aos treinamentos específicos que as pessoas receberam (ou não) ao longo de suas vidas escolares e/ou profissionais. Esse problema metodológico de captação dos dados (de difícil solução), torna-se ainda mais grave no caso brasileiro, dada a notória deficiência de nosso sistema educacional básico.

Há ainda outros fatores que, em um país como o Brasil, tendem a incrementar ainda mais as assimetrias arroladas por Proenza no comentário acima citado. Comecemos pela clivagem do espaço nacional entre urbano e rural. Num país como o Brasil, cujo processo histórico de industrialização foi marcado por elevada heterogeneidade setorial, convivem, tanto no campo, quanto na cidade, estruturas produtivas de diferenciadíssimos graus de produtividade.
Na zona rural, existem desde as práticas produtivas não-mercantis, ou seja, voltadas à subsistência, até os grandes grupos capitalistas do agronegócio de grande rentabilidade e competitividade internacional. Entre esses extremos, convivem diversas pequenas e médias propriedades que produzem para o mercado e cuja expansão econômica poderia ser bastante incrementada por um eventual acesso à Internet, pelas facilidades de realização de negócios e de obtenção de informações úteis para a compra de insumos, para o desenvolvimento das técnicas produtivas e para as práticas comerciais. Mas, dadas as enormes diferenças de produtividade e de renda dessas atividades, é de se esperar que o acesso à Internet (a inclusão digital) seja também bastante diferenciado, criando novo fator de criação de assimetria entre essas empresas.

No caso das atividades do setor urbano, aplica-se o mesmo raciocínio. Ou seja, as diferenças de produtividade entre os setores e a pronunciada heterogeneidade do espaço econômico brasileiro não podem ser simplesmente descritos por uma dualidade rural/urbano, mas por elevados níveis de diferenças dentro de cada um desses segmentos e entre eles também. Sendo assim, as oportunidades extraordinárias disponibilizadas aos pioneiros do acesso digital (conforme destaca corretamente Proenza) são grandemente aumentadas em uma estrutura produtiva marcada pela heterogeneidade da estrutura produtiva brasileira.

Para reforçar, podemos também mencionar os baixos níveis de rendimentos das pessoas e dos pequenos negócios (do campo e da cidade), que muitas vezes os impedem de serem digitalmente incluídos, pois, para tanto, é preciso ter, pelo menos, uma linha telefônica e um computador.

\section{O N C L U S Ã O}

As informações e dados apresentados e analisados neste estudo mostram que a chama- 
da Era da Informação não tem se caracterizado pela apregoada convergência de que tanto têm falado os "tecno-utopistas".

A mesma literatura de exaltação às supostas excelências do atual processo de globalização é a que também avalia de forma ufanista e apologética os efeitos das novas tecnologias nas sociedades atuais.

É preciso levar em conta que questões como inclusão social, redução da pobreza e da desigualdade de renda e de riqueza entre pessoas e entre países não são resolvidas apenas pela evolução tecnológica. Se o fossem, não estariam se arrastando e tornando-se cada mais vez mais complexas com o passar dos séculos (uma vez que a evolução tecnológica não é prerrogativa apenas desses tempos das chamadas "novas tecnologias", evidentemente).

Os problemas arrolados neste artigo, relacionados às assimetrias geradas pelo capitalismo, são de grande complexidade e não se resumem a fatores tecnológicos. Dependem, fundamentalmente, de fatos políticos e sociais, que geram efeitos econômicos e transformam as sociedades em sociedades mais igualitárias e democráticas. São, em suma, uma questão de Poder, conforme salientam, entre outros, Bascur (1984), Fiori (2001a) ${ }^{32}$ e Fiori (2001b).

A História do Capitalismo apresenta algumas situações de redução de desigualdades de renda entre pessoas em certos países (como na Europa Ocidental do pós-Segunda Guerra, por exemplo) ou do aumento da participação da renda de uma certa nação na renda mundial (como revela a história dos EUA e também a história recente da China (Tabela 8). Mas esses fenômenos são de enorme complexidade e relacionam-se a importantes transformações sociais, políticas, culturais e, muitas vezes também, de ações bélicas.

Aos tecno-ufanistas seria necessário perguntar porque as "novas" tecnologias (que sempre surgiram na História da Humanidade, não é um privilégio do momento atual) poderiam promover os efeitos homogeneizadores que as anteriores não conseguiram?

Não podemos negar, de qualquer forma, que as novas Tecnologias das Informação e da Comunicação geraram importantes transformações no mundo do trabalho (MARQUES, 2002), na estratégia das empresas e nas relações sociais. Não há, porém, elementos para afirmar que tenham reduzido as diferenças de renda entre as Nações ou as desigualdades de renda entre as pessoas. Pelo contrário. Parece mesmo que o potencial concentrador do Capitalismo (notadamente em sua fase atual, da globalização neoliberal desregulamentadora) tem sido aprofundado pelas novas Tecnologias da Informação e da Comunicação.

Não se pode negar, tampouco, o papel que a Internet pode ter na promoção da Demo-

\footnotetext{
32 Fiori (2001a, p.76-77) é peremptório na seguinte passagem, que merece ser citada: “Não há a menor dúvida de quea Internet pode contribuir para o avanço democrático, tanto quanto contribuíram, no seu tempo, a imprensa escrita, o telégrafo, 0 rádio, a televisão etc. 0 que al guns esquecem é que o principal obstáculo à democracia das sociedades capitalistas nunca foi a existência ou não das informações, mas a propriedade ou o controle de sua produção, seleção e divulgação massiva. É verdade que, no caso da Internet, qualquer pessoa que disponha, no mínimo, de eletricidade, tel efone e computador, pode produzir e fazer circular suas informações entre os amigos, não havendo impedimento para que as forças "anti-sistêmicas" também façam o mesmo. Também não havia impedimentos, nas sociedades democráticas tradicionais, à publicação de jornais de circulação restrita e ao funcionamento posterior de "rádios livres" ou de televisões comunitárias. 0 problema não está aí, porque o essencial, do ponto de vista da democratização, não tem a ver com problemas técnicos de comunicação, nem com formas mais ou menos sofisticadas de cadastramento de el eitores, voto por tel efone celular, ou qualquer outro tipo de "e-democracia". O avanço ou retrocesso das lutas democráticas nunca foi um problema tecnológico, sempre foi um problema de poder. E não é provável, tampouco, que as "redes" eliminem a necessidade de que as pessoas compartam fisicamente experiências coletivas e organizações permanentes na "guerra de posições" secular dos oprimidos contra os donos do poder". Para discutir essas questões, também convém sugerir a leitura, pelo menos, do primeiro capítulo de Bolaño (2000).
} 
cracia, na inclusão social, na ampliação das oportunidades profissionais e ainda nas possibilidades de entretenimento, ensino e lazer das pessoas no momento atual e no futuro. O que não se pode afirmar é que a simples existência da Internet e das Tecnologias de Informação, de Mídia e de Comunicação poderá gerar um mundo mais homogêneo e até, como dizem alguns, um mundo de paz (sic) $)^{33}$.

Os apologetas da globalização e da Internetnão contribuem para um debate qualificado, mas são hegemônicos no mundo acadêmico. Resta aos seus adversários investigarmos, de forma mais profunda, os fenômenos que têm sido produzidos por essas novas tecnologias e retomar o debate sobre seus efeitos sobre as sociedades atuais, não levando em conta apenas o fascínio que de fato as tecnologias, de qualquer maneira, provocam em todos nós. É preciso interpretar criticamente as transformações recentes e fazê-lo de forma a evitar os argumentos alienantes e desmobilizadores dos que analisam os fatos com base em um certo determinismo tecnológico ${ }^{34}$, conforme crítica de Garnham a Castells.

No caso de um país como o Brasil, é urgente a necessidade de encarar de forma ampla e qualificada o atual debate sobre exclusão digital, conforme defendem Silveira (2001) e Bolaño (2003a) e (2003b), entre outros.

É preciso que o Estado se debruce nesta questão de forma decidida, como forma de articular políticas públicas que possam não somente ampliar o acesso de pessoas de baixa renda e de empresas familiares ou artesanais à Internete, conseqüentemente, às possibilidades que tal acesso abre a todos que a ela se integram. É necessário também que medidas de caráter material (compra de equipamentos, ampliação de linhas telefônicas, etc.) sejam acompanhadas de medidas relacionadas à educação formal e ao treinamento específico (para a utilização dessas tecnologias) em prol dos socialmente excluídos, de forma a ampliar a capacidade cognitiva dos mesmos, ou seja, de forma a dotá-los de cada vez maior capacidade de exploração, de interpretação e de uso do enorme mundo de informações disponibilizado pela Internet.

Por fim, devemos reforçar nossos argumentos lembrando que, em uma sociedade organizada segundo a lógica do mercado, a evolução tecnológica não vai trazer, por si só, a homogeneização regional, social e muito menos mundial. Deve-se destacar que essas questões estão relacionadas às relações entre Democracia-Poder-Comunicações, algo bastante complexo nas sociedades capitalistas, notadamente após o processo de desregulamentação que se impôs (por ação dos Estados Nacionais e das elites econômicas dos diversos países) sobre as atividades midiáticas desde pelo menos os anos 1970 (quando foram sendo diluídas as medidas regulamentadoras que haviam sido constituídas no pós-Segunda Guerra). A desejada homogeneização que poderia ser conseguida com as novas TIC dependerá da maneira pela qual ocorrerá a difusão e massificação da Internet, o que inclui aspectos institucionais, organizacionais e jurídicos que afetem a difusão das informações. Dependerá também da forma de organização da chamada sociedade civil em prol de atividades cidadãs de educação formal e digital, de forma a aumentar a capacidade crítica

33 A análise da complexidade dos fenômenos de transformação social não pode ser feita apenas sob os auspícios das transformações tecnológicas, sob o risco de se incorrer em erros graves, ao analisar apenas a exterioridade dos processos de mudanças sócio-econômicas.

${ }^{34}$ A esse respeito, seria interessante registrar passagem em que Fiori (2001a, p.43-44) cita Mattelard (1997): “ a tecnoutopia se revela uma arma ideológica de primeira grandeza ao se propor naturalizar a visão livre-cambista da ordem mundial (...) é necessária a miopia dos tecnolibertários para apoiar a representação simplista de um Estado abstrato e maléfico, oposto a uma sociedade civil idealizada, vista como um espaço liberado de comunicação entre indivíduos plenamente soberanos". 
das pessoas ${ }^{35}$, capacitando-as a transformarem as informações em conhecimento, tanto para suas respectivas atuações profissionais, como também para sua atuação como sujeitos políticos em sociedades cada vez mais marcadas pela desigualdade social e pela falta de esperança na Democracia.

\section{REFERÊ N C I A S}

ANUÁRIO DOS TRABALHADORES. São Paulo: Dieese, 2001. 199p.

BELL, D. El advenimiento de la sociedad post industrial. Madrid: Alianza Editorial, 1973. 540p.

BOLAÑO, C.R.S. Indústria cultural, informação e capitalismo. São Paulo: Hucitec, 2000.

BOLAÑO, C.R.S. Economia política da Internet. Aracajú: Universidade Federal de Sergipe, 2003a.

BOLAÑO, C.R.S. Políticas de comunicação e economia política das telecomunicações. 2003b. Disponível em: <www.eptic.com.br>. Acesso em: nov. 2003.

BOLAÑO, C.R.S.; MATTOS, F.A.M. Conhecimento e capitalismo: para a crítica da sociedade da informação. 2003. Mimeografado.

BRAVO, P.V. A distribuição da renda e as opções de desenvolvimento. In: SERRA, J. (Org.). América Latina: ensaios de interpretação econômica. Rio de Janeiro: Paz e Terra, 1979. p.83-105.

BRENNER, R. Towards the precipice. London Review of Books, London, v.25, n.3, 2003. Disponível em: <www.pulp.net>. Acesso em: nov. 2003.
A questão da inclusão digital, em suma, é uma questão de Poder (RHEINGOLD, 1996). Não se resume a uma discussão meramente estatística, conforme, aliás, sublinhou argutamente Schwartz em passagem que escolhemos como epígrafe deste artigo.

CASTELLS, M. A sociedade em rede. São Paulo: Paz e Terra, 1999. (A era da informação: economia, sociedade e cultura, v.1).

CASTELLS, M. Plano Marshall tecnológico nortesul. Folha de S. Paulo, São Paulo, 20 ago. 2000. Caderno Mais!

CHESNAIS, F. A mundialização do capital. São Paulo: Xamã, 1996. 335p.

COUTINHO, L. Notas sobre a natureza da globalização. Economia e Sociedade, Campinas, n.4, p.21-26, 1995.

COUTINHO, L.E.; BELLUZZO, L.G.M. "Financeirização" da riqueza: inflação de ativos e decisões de gasto em economias abertas. Economia e Sociedade, Campinas, n.11, p.137-150, 1998.

FARAH, P.D. Nem 5\% do mundo usa Internet, diz ONU. Folha de S.Paulo, São Paulo, 23 jun. 2001. Caderno Dinheiro.

FIORI, J.L. A idiotia da novidade. In: FIORI, J.L. Brasil no espaço. Petrópolis: Vozes, 2001a. 268p.

FIORI, J.L. 60 Lições dos 90. Rio de Janeiro: Record, 2001b.

FUKUYAMA, F. The end of history and the last man. New York: Free Press, 1992. 237p.

\footnotetext{
35 Bolaño (2003a) sublinha, na seguinte passagem, alguns condicionantes que são decisivos para que se possa construir uma sociedade baseada no papel da Internet como difusora da comunicação entre as pessoas, procurando, de passagem, criticar al guns mitos sobre as supostas "novidades" que adviriam com a tecnologia da Internet: "(...) a capacidade de comunicação e de acesso à informação relevante [pela Internet] depende justamente daqueles el ementos que no passado garantiam o acesso à esfera pública liberal: poder econômico (propriedade), político e conhecimento, nessa ordem de importância." (p. 18). A seguir, porém, o autor destaca que, dependendo de certas condições, a Internet tem potencial transformador significativo nas sociedades atuais: "o modo de consumo, como o modo de produção, torna-se mais comunicacional e informático, alterando as relações sociais e a própria estrutura do mundo da vida de amplas camadas da população mundial incluída nos processos de reprodução do capital. Mais informação e comunicação, no mundo do trabal ho e no mundo da vida, pode tornar-se, sob determinadas condições (grifo nosso), mais informação e comunicação a serviço de um projeto libertador, alternativo, anti-capitalista".
} 
GARNHAM, N. La sociedad de la información como ideología: uma crítica. In: FORO DE LAS COMUNICAICONES, 1., 2000, Santiago (Chile). Santiago: Unicom, 2000. p.1-20.

GREIDER, W. One world, ready or not: the manic logic of global capitalism. New York: Simon \& Schuster, 1997. 528p.

HIRST, P.; THOMPSON, G. La globalizzazione delle'economia. Roma: Editori Riuniti, 1999. 287p.

KAPSTEIN, E. Governare la ricchezza: il lavoro nell'economia globle. Roma: Carocci Editore, 1999. $185 p$.

KOZUL-WRIGHT, R. Transnational corporations and the nation state. In: MICHIE, J.; SMITH, J.G. (Ed.). Managing the global economy. Oxford: Oxford University Press, 1995. p.135-170.

LÉVY, P. Cibercultura. São Paulo: Editora 34, 1999. p.175-176.

LOZADA, M. (2003). Política em red y democracia virtual: la cuestión de lo público. In: MATO, D. Estudios latinoamericanos sobre cultura $y$ transformaciones sociales en tiempos de globalización. Buenos Aires: CLACSO, 2001. p.133-146.

MAPA DA EXCLUSÃO DIGITAL. Rio de Janeiro: FGV;IBRE, 2003. 143p.

MARQUES, I.C. O Brasil e a abertura dos mercados: o trabalho em questão. Rio de Janeiro: Contraponto, 2002. 103p.

MATTOS, F.A.M. A importância do estudo da evolução da distribuição da renda do trabalho. Cadernos da FACECA, Campinas, v.4, n.1, p.76-87, 1995.

MATTOS, F.A.M. Transformações nos mercados de trabalho dos países capitalistas desenvolvidos a partir da retomada da hegemonia americana. 2001. 305f. Tese (Doutorado em Economia do Trabalho) - Instituto de Economia, Universidade Estadual de Campinas, Campinas, 2001.
MILEWSKI, F. Les marges de manoeuvre des politiques économiques. In: CORDELLIER, S.; DOUTAT, F. (Coord.). Mondialisation: au-dela des mythes: les dossiers de l'état du monde. Paris: La Découverte, 1997. p.119-133.

OHMAE, K. The end of the nation state: the rise of regional economies. New York: Free Press Paperback, 1996. 212p.

PARK, D. An examination of global income convergence for 1960-1990. Journal of Economic Development, v.22, n.1, p.1-28, 1997.

PINTO, A. Heterogeneidade estrutural e modelo de desenvolvimento recente. In: SERRA, J. (Org.). América Latina: ensaios de interpretação econômica. Rio de Janeiro: Paz e Terra, 1979. p.44-82. PROENZA, F. E-para todos. In: SILVEIRA, S.A.; CASSINO, J. (Org.). Software livre e inclusão digital. São Paulo: Conrad, 2003. p.133-185.

RHEINGOLD, H. A comunidade virtual. Lisboa: Gadiva, 1996. 367p.

SCHUMPETER, J. Capitalismo, socialismo e democracia. Rio de Janeiro: Zahar, 1942.

SCHWARTZ, G. Exclusão digital entra na agenda econômica mundial. Folha de S. Paulo, São Paulo, 18 jan. 2000. Caderno Dinheiro, p.B2.

SILVEIRA, S.A. Exclusão digital: a miséria na era da informação. São Paulo: Fundação Perseu Abramo, 2001. 47p.

TAVARES, M.C. A retomada da hegemonia norte-americana. In: TAVARES, M.C.; FIORI, J.L. (Org.). Poder e dinheiro: uma economia política da globalização. Petrópolis: Vozes, 1997. p.27-53.

TAVARES, M.C. Globalização e crescimento desigual. Cultura Vozes, São Paulo, n. 5, 1998. p.2-8.

UNITED STATES. General Accounting Office. Telecommunications: characteristics and choices of internet users. February, 2001.

WELLER, C.; HERSH, A. Free markets and poverty. The American Prospect, Washington, DC, v.13, n.1, jan1-jan14, 2002. 
